\title{
Perception of nursing in Primary Health Care about patients with hypertension: does King explain?
}

\author{
Percepção da enfermagem na Atenção Primária à Saúde acerca do paciente com hipertensão: King explica? \\ Percepción de enfermería en Atención Primaria de Salud sobre el paciente con hipertensión: ¿King explica?
}

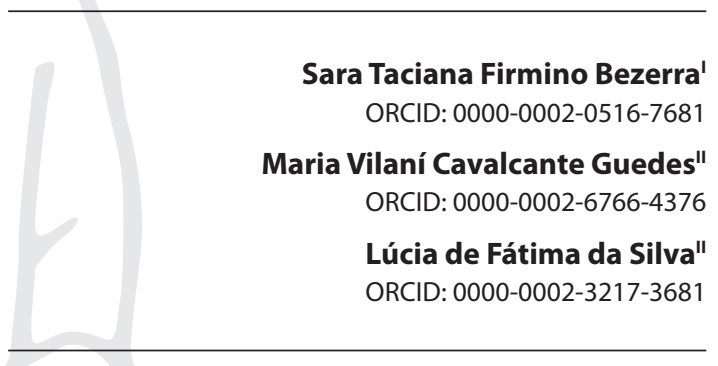

'Universidade do Estado do Rio Grande do Norte. Pau dos Ferros, Rio Grande do Norte, Brazil. "Universidade Estadual do Ceará. Fortaleza, Ceará, Brazil.

How to cite this article: Bezerra STF, Guedes MVC, Silva LF. Perception of nursing in Primary Health Care about patients with hypertension: does King explain? Rev Bras Enferm. 2020;73(Suppl 6):e20190676.

doi: http://dx.doi.org/10.1590/0034-7167-2019-0676

Corresponding author:

Sara Taciana Firmino Bezerra

E-mail: sarataciana@uern.br

EDITOR IN CHIEF: Dulce Barbosa ASSOCIATE EDITOR: Ana Fátima Fernandes

Submission: $02-20-2019$

Approval: 07-25-2020

\begin{abstract}
Objectives: to understand nurses' perceptions about Imogene King's concepts on CMIOS and its association with caring for patients with hypertension in Primary Health Care. Methods: a qualitative interventionist research with Family Health Strategy nurses who care for patients with hypertension at Primary Health Care in Maracanaú-CE. A focus group was held with seven nurses, in two audio-recorded and transcribed meetings, to analyze the production of meanings based on discursive practices. Results: the categories personal system, interpersonal system, and social system emerged referring to the potentialities and difficulties found both for understanding concepts, but also in the interaction with oneself, with hypertensive patients and health organization, with a view to adequate care for hypertensive patients. Final Considerations: it was verified the understanding of nurses' knowledge in relation to King's concepts, associating its application in the context of care for patients with hypertension.

Descriptors: Nursing; Nursing Theory; Office Nursing; Primary Health Care; Hypertension.
\end{abstract}

\section{RESUMO}

Objetivos: compreender as percepções de enfermeiros acerca dos conceitos do MCSA de Imogene King e sua associação com o cuidado do paciente com hipertensão na Atenção Primária à Saúde. Métodos: pesquisa qualitativa, intervencionista, com enfermeiras da Estratégia Saúde da Família que atendem pacientes com hipertensão na Atenção Primária à Saúde de Maracanaú-CE. Realizou-se grupo focal com sete enfermeiras, em dois encontros audiogravados e transcritos, para análise da produção de sentidos com base nas práticas discursivas. Resultados: surgiram as categorias sistema pessoal, sistema interpessoal e sistema social, referindo as potencialidades e dificuldades encontradas tanto para compreensão dos conceitos, mas também na interação consigo mesma, com o paciente hipertenso e com a organização em saúde, com vistas ao cuidado adequado ao hipertenso. Considerações Finais: constatou-se a apreensão do conhecimento das enfermeiras em relação aos conceitos propostos por King, associando-se a sua aplicação no contexto do cuidado ao paciente com hipertensão.

Descritores: Enfermagem; Teoria de Enfermagem; Enfermagem no Consultório; Atenção Primária à Saúde; Hipertensão.

\section{RESUMEN}

Objetivos: comprender las percepciones de las enfermeras sobre los conceptos de la MCSA de Imogene King y su asociación con la atención de pacientes con hipertensión en Atención Primaria de Salud. Métodos: investigación cualitativa intervencionista con enfermeras de la Estrategia Salud de la Familia que atienden a pacientes con hipertensión. en Atención Primaria de Salud en Maracanaú-CE. Se realizó un grupo focal con siete enfermeras, en dos reuniones grabadas y transcritas en audio, para analizar la producción de significados a partir de prácticas discursivas. Resultados: surgieron las categorías sistema personal, sistema interpersonal y sistema social, referidas a las potencialidades y dificultades encontradas tanto en la comprensión de los conceptos, como en la interacción con uno mismo, con el paciente hipertenso y con la organización sanitaria, con miras a una adecuada atención al paciente hipertenso. Consideraciones Finales: se encontró la aprehensión de conocimiento de las enfermeras en relación a los conceptos propuestos por King, asociando su aplicación en el contexto de la atención al paciente con hipertensión.

Descriptores: Enfermería; Teoría de Enfermería; Enfermería de Consulta; Atención Primaria de Salud; Hipertensión. 


\section{INTRODUCTION}

Nurses'knowledge emerges from their practice, from interaction with patients, maturing through research, grounding their science and strengthening the articulation between theory, research, and practice. In this regard, knowledge and research development must take place in nursing practice, since care represents nursing know-how ${ }^{(1)}$. Moreover, the opposite occurs when this knowledge directs, guides and updates nursing practice. This occurs with a view to providing health promotion, protection, and rehabilitation. Therefore, it must be carried out based on scientific knowledge, combined with the acquired experience, in order to improve praxis.

Using the nursing framework allows nurses to conceive and guide their practice, in order to identify specific needs of each person, family or community with a holistic approach to patients. Therefore, it is necessary to elucidate the elements of nursing care as an epistemological structure for the interpersonal relationship that occurs among nurses and their object of care ${ }^{(2)}$.

In 1981, Imogene King presented the Conceptual Model of Interactive Open Systems (CMIOS), the basis for understanding that nursing care takes place through nurse-patient interaction. Both constitute a personal system and the meeting of these personal systems initiates the nursing situation in the interpersonal system singularly, in a temporospatial reality, in which nurses and patients establish an interaction. From this model, problems, resolution goals and action strategies involving the social system in which they are inserted are identified ${ }^{(3)}$.

Given the above, the questions that guide the present study are: how do nurses understand CMIOS? Furthermore, how to use these concepts in the interaction with hypertensive patients?

Not disregarding other models of nursing care, in this work we defend that nurses can use this conceptual model in caring for hypertensive patients. This is a complex being and adherence to treatment comprises individual and collective factors that permeate their lives. It appears that the inadequate functional literacy of hypertensive people today is associated with poor disease control in primary care ${ }^{(4)}$. This, on the other hand, resulting from blood pressure reduction, is associated with a concomitant cardiovascular risk reduction ${ }^{(5)}$.

We hope that nursing will strengthen the relationship between theory and practice in patient care. CMIOS can favor nurse-patient interaction in public health, not being limited to patients with hypertension ${ }^{(6)}$, as nurses get closer to this knowledge and experience its usefulness for clinical nursing practice.

\section{OBJECTIVES}

To understand nurses' perceptions about Imogene King's concepts on CMIOS and its association with caring for patients with hypertension in Primary Health Care.

\section{METHODS}

\section{Ethical aspects}

This study was approved by the Research Ethics Committee of Universidade Federal do Ceará, under Opinion 459,715. Participants' rights have been ensured, in addition to continuous reflection on participation during the study. They were informed about the objectives and involvement in data production. Participants were requested to sign the Informed Consent Form and permission to record and guarantee availability to clarify any doubts.

\section{Theoretical-methodological framework and type of study}

Imogene King presents CMIOS, in which she defines human beings as open interactional systems: personal, interpersonal and social. Nurses and patients are considered personal systems and the interaction between them occurs in the interpersonal system ${ }^{(3)}$.

The personal system comprises the world of experiences in which human beings process information from the environment, organize and categorize their perceptions. For this reason, categories (concepts) help people to relate past experiences to current events and give meaning and stability to their world. King proposes concepts to assist nurses in understanding this system, such as perception, self, body image, growth and development, time, and space ${ }^{(3)}$. Knowing and understanding these concepts allows nurses to equip themselves with strategies to enable an effective interaction with the individual to be cared for, as they recognize their potential and limitations, as well as that of the other.

Perception is one of the basic concepts in the Open Systems Structure, understood as each representation of reality made by human beings, influencing all their behaviors and demonstrating an awareness of the world and focused on the present. Perception is the proper constitution of a composite of thoughts and feelings that allow constructing individual existence, the idea that people are what distinguish them from the outside world. Growth and development are interrelated concepts that involve physical and chemical changes resulting from the quantitative and qualitative phases of human organisms, transforming their cellular, physical and behavioral structure. Body image is the perception of one's own body, limited in space, the perception of the other's reactions to his appearance and results from the other's reactions to himself. Space exists to the extent that it is perceived by each person, it exists in all directions and in all places. Time is not only seen as the order of events, but the duration experienced by each person, is an interval between one event and another experienced by each individual, the relationship of one event to the other and only those who experience it can define $i t^{(3)}$.

The crises to which each individual is susceptible can involve identity disorders of body image, emotional, physical, involving each of the personal system's concepts. Such fact becomes an essential element for nurses who care, in order to plan interventions consistent with each person's health status.

Human interactions allow the interpersonal system to exist through communication, transactions, role, and stress ${ }^{(3)}$.

Communication can be verbal, non-verbal, situational, transactional, irreversible and dynamic. Symbols, which make up spoken and written language, touch, distance, attitude, facial expression, physical appearance, body movements are elements of communication with different meanings in human interaction. Transaction represents a life situation in which perceivers and perceived things find themselves and in which each person 
enters the situation as an active participant and changes in the process of these experiences. For this reason, transaction has a temporal and spatial dimension that constitutes experiences. Interactions are acts of two or more people in mutual presence, which can reveal how one person thinks and feels for the other, how each one perceives the other and the other does for him or her, what his or her expectations are and how he reacts to his or her actions. Role is the function that people perform in their space, what is expected of them in a certain position in the organization. Stress are essential human experiences, which can be physical, environmental, chemical, psychological, emotional and social, and their intensity changes the individual's perception and condition, making it negative or positive, constructive or destructive depending on the way of coping.

People interaction generates action and a sequence of behaviors including: (1) mental action - recognition of present conditions; (2) physical action - start of operations or activities related to conditions or situation; (3) mental action (to exercise control over events) and physical action (to attain goals). When they actively participate in events, on the move to attain goals, transactions occur, the result of changes in the individuals involved in the interaction ${ }^{(3)}$.

Nursing is considered as a process of action, reaction and interaction, in which nurses and patients share information about their perceptions in the nursing situation. With intentional communication, they identify problems, concerns and goals and explore ways and agree with them to attain a goal. It was believed that when clients participate in setting goals with professionals, they interact for their reach ${ }^{(3)}$.

The social system is defined as an organized limit system of social functions, behaviors and practices in order to maintain values and regulation of practices and standards. Some functional elements exist in organizations such as roles, position, lines of authority and communication. The concepts for social system are organization, authority, power, status, and decision-making ${ }^{(3)}$.

Organization is a complex institution made up of individuals and groups performing continuous activities, designed to attain goals. Authority is the power to make decisions for one's own actions and those of others. If $A$ perceives $B$ as someone who can legitimately make decisions, then B has authority over A. Power is the ability or ability of a person or group to use resources in organizations to attain goals, or the social force that organizes and maintains society. Status is the position of an individual in the group as perceived by others, the prestige linked to the role played in the organization; therefore, status is situational and reversible. When a person loses his or her place in the organization that was perceived by others as having prestige, he or she loses status in the organization. Finally, decision-making is a process of choosing an alternative among many, based on facts and values, implementing decisions and assessing goal attainment. Decisions regulate the organization activities and people's lives ${ }^{(3)}$.

Nurses have a crucial role in health organizations, as active participants in decision-making that influence the quality of care, exercising leadership, setting institutional, individual and professional goals to maintain harmony. Nurses must demonstrate clarity in their role to take over the leadership required in the team, in order to maintain organizational values ${ }^{(3)}$.
Based on the presented framework, a qualitative interventionist research was carried out with professional nurses, in order to know the impressions, difficulties, doubts and problems identified in the discussion about the theoretical foundation for the practice of nursing in public health. For performance, the action research modality was selected ${ }^{(7)}$. It is a type of social research with an empirical basis associated with an action, in which researcher and participants get involved in a cooperative or participatory way. In the description, COREQ was used to detail the research steps.

\section{Study setting}

The research was conducted with the Maracanaú Department of Health, located in the metropolitan region of Fortaleza-CE, in the auditorium of a Basic Family Health Unit.

\section{Data source}

Ten nurses have been invited in a joint meeting to participate in the research, among the 53 that were part of Family Health Strategy (FHS) teams, assigned by the technical coordinator. After discussing the research, its objectives for the researcher's PhD, and signing the Informed Consent Form, the first meeting had been scheduled. However, seven nurses participated, called Tulip, Gerbera, Camellia, Lily, Flame Lily, Amaryllis, and Alpina, for participant anonymity; the rest refused. All were women, young (between 22 and 30 years old), FHS nurses for at least 2 years.

\section{Collection and organization of data}

Two articles were made available to nurses to bring them closer to CMIOS. For data production, the focal group technique was performed in two meetings, on March 26 (85 minutes) and April 16, 2014 (55 minutes), in an auditorium, with adequate space and acoustics for data collection.

The chairs were arranged in a circle to facilitate member visualization and followed the recommendation of 7 to 10 participants. The main researcher, nurse and doctoral student (at that time), mediated the meetings and two assistants (nursing students) recorded and recorded them. Both took a previous course on action research and were trained for the focus group.

In both meetings, the panel dynamics were carried out, simulating $\mathrm{CMIOS}^{(3)}$. Each participant received concepts from CMIOS and placed each word on the panel, inserting it in the space they considered appropriate for the personal, interpersonal, and social systems. Then, she explained about the concept, how she thought the concept appears in her daily life, in her care practice for people with hypertension. Finally, each concept was presented and discussed, making adjustments when there was an error, to discuss when the group's thinking agreed or disagreed with the ideas of the American theorist. In this regard, the data were discussed in groups until no new elements were in doubt; however, the transcript was not returned to participants.

\section{Data analysis}

Audio transcription was performed by the auxiliaries and ratified by the main researcher, using Word. The data produced were 
analyzed following the production of meanings, supported by discursive practices $^{(8)}$. Through this reading, it is possible to understand the interanimation process that makes research a social practice.

Map construction begins by defining the general categories, which reflect the objectives of the research. Therefore, personal system, interpersonal system and social system started from CMIOS. The aim is to organize the contents based on these categories, preserving the sequence of speeches and identifying dialogic interanimation processes in the visual layout of the interview ${ }^{(8)}$. The nurses received the results and confirmed their perception of CMIOS. The results exemplify the participants' statements, demonstrating the consistency of the findings.

\section{RESULTS}

\section{Personal System}

The first concept presented was body image, seen as "the figure I have of my body limited in space", which is an aspect of the idea of self, influenced by sociocultural factors ${ }^{(3)}$.

Thus, not only the appearance, the issue of intimate hygiene and care they have. Hypertensive and diabetic patients must have their weight and overweight assessed due to their feet. (Amaryllis)

The second concept selected by the group was perception. Initially, it was addressed how nurses perceive patients and vice versa.

Every time a patient comes, you have to look for what they are feeling at the time of illness; if they are healthy, you should not form that stereotype that patients are always angry, always sad. They are constantly changing. (Lily)

The first time you are annoying, you are already judged as a boring person; it's because they really have the perception. There are some who arrive and you can see that they are really fussy, there is no way not to call them fussy, "I just came to get my medications". (Gerbera)

The concept of self was situated in the personal system, but the nurse who said that word had no idea of its meaning.

That's exactly what I was talking about. In a way, these words are new to me, and I think it is exactly your intention, our practice with theoretical knowledge, because we have superficial theoretical knowledge, experience is what makes us master. (Tulip)

King reports that time is universal; therefore, there was no difficulty in discussing this concept, with good participation by the members.

Many say, "I have to cook lunch"; there are some who say, "no, no, I have to be seen soon, because I'm still going to cook lunch and pick up my granddaughter at school'. (Tulip)

When she left and the door was closed, I said, "Now, she can help us first because we are housewives, and we can go back home and cook lunch". (Camellia)
The concept of development has been addressed. Nurses associated this concept with maturity to understand the disease and the attitudes necessary for its control. Thus, patients are well regarded when they already know about hypertension and follow the recommendations made in the consultation.

But it's funny when there is the type of patient who has problem to understand orientation, they pay attention to what you say, "Okay, next time I'm going to get better", as if we were scolding him and that the next time he will get better for us not to fight; but when the patient is very old and unaccompanied, it is hard to explain, to say it very well, for that companion to help. (Flame Lily)

Growth and development involve cellular, molecular and behavioral changes, influenced positively or negatively by another person and by the environment, having a great impact when a disease is diagnosed ${ }^{(3)}$.

The last concept of the personal system, space, discussed in the focus group had not been expressed in this system, but in the interpersonal system. Thus, it was necessary to draw members' attention to this concept.

Space itself is already saying, space to work, space to develop actions; I think physical space and permission space, so there must be space too; the space that the hypertensive, asthmatic patient lives. I arrived at her house, her room was pure mold, with scattered cigarette butts, only then do you see the space she lives in, how are you going to solve this? She does not preserve her home. (Flame Lily)

\section{Interpersonal System}

The first word presented was communication for the interpersonal system, a basic instrument of nursing. Communication, as a fundamental social process, develops and maintains human relationships and facilitates the orderly functioning of human groups and societies ${ }^{(3)}$.

I'll start with the communication, which I think is very important for the interpersonal system, it is the way you behave in front of patients; if they understood what you said, if you are not making faces, calling them boring in your subconscious, [laughs] everything that verbal and non-verbal communication shows. In the end, find out if they understood you, because during the interpersonal relationship it is important that they understood you and that you understood their deficiencies, what they were expecting from you too. Sometimes, we speak technical terms, we receive the interns, they [patients] did not understand anything, "speak again", translate into their language. When the person has an expression of doubt, I translate, "when you speak there is no use speaking like that, they will not understand". (Gerbera)

Nurses understand their role with hypertensive patients, as someone who can help them cope with their disease, by providing attention, listening and coping strategies. On the other hand, they also show concern regarding the reality of patients.

But it is very difficult to set goals when the person is in no condition to eat, my hypertensive patients are extremely poor. I went to visit and we were talking about omeprazole, then the doctor said, 
"hey, Alpina, she will never get better, look what she eats", she eats manioc flour thickened broth for lunch, she will die eating flour and with stomach pain. Patients may even have money at the beginning of the month, then they buy fruit, but in the middle of the month they no longer have money, they will eat what is available. (Alpina)

We are almost mothers for patients, almost, because we almost say, "my son, for God's sake, we are going to do the treatment, otherwise you will die". (Gerbera)

Participants discussed both the stress experienced by them and the stress perceived in hypertensive patients.

Ours or theirs? We need to take care of our stress, the responsibility that is not small, and the community, is a lot of people, work overload. (Flame Lily)

It is because the secretary staff stress us out, [laughs] the secretary and mayor stress us [laughs]. When we pass, the stress will be worth it, but if it doesn't, we will get mad. (Gerbera)

The concept of transaction had been wrongly placed in the personal system, but its meaning was explained to the group participants, as the sense of transaction was confused with the sense of growth. Growth is the person's physiological transformations, whereas the transaction consists of cognitive changes, perceived individually in the process of interactions, when goals are attained ${ }^{(3)}$.

I asked him to do the ABPM [Ambulatory Blood Pressure Monitoring], which was always high, 16×10, 17x10. I thought it was more related to the habit of life than medication, I said, "let's do this, check your blood pressure", I made a map for him to mark BP and time, I advised on food, physical activity, to avoid this, avoid that. Today he came to me out of the blue and said, "Camellia, remember what you told me? Look here at my pressure, 13x8", I mean, it was a considerable improvement that I didn't need to pass on, because if I passed it on to the doctor, at the same time he was going to prescribe a medication and bye-bye, understand? So, it wasn't the medication, I said "keep it up, but you have to go to the doctor, you will bring what you did for him to look at". (Camellia)

I have a patient who told her that her husband works at CEASA [Central de Abastecimento do Ceará], "woman, your husband works at CEASA", lexplained everything, after about 6 months she came back to me and said, 'Lily, look, are you noticing any difference?', he gave me both papers saying $91 \mathrm{~kg}$ and $101 \mathrm{~kg}$ [current and previous weight]. I felt so happy, with such high self-esteem, "look at my waist", her pressure. Other than that, her disposition has improved, because she is walking every day, her pressure has decreased, you will notice the evolution. (Lily)

\section{Social System}

In the social system, the first concept discussed was organization. The nurses started the discussion by approaching this concept as a necessary quality for this professional so that her work is well performed. This was a misunderstanding by the participant.

Organization, nursing is already a profession that requires a lot of organization, because if you are not an organized nurse everything goes wrong. We have to be organized with our agenda, we cannot leave our agenda only in the hands of the reception staff. (Flame Lily)

The organization is also part of the health agent with this patient, here comes our agenda. The organization of that day attending only hypertensive patients, consultation organization. (Tulip)

The Health Office must have a secretary to be organized, must have a coordination, because if everything were disorganized, we would not have a guide that said, "look, these are the goals". I think that organization means that each one has his or her goal, each one goes through what is needed to be gone through, people are scolded, but if there is a flowchart, organization gets easier. So, I think it comes from the federal institution until it arrives at the unit, even the health agents, so everything is an organization. (Gerbera)

The group sees decision making as a result of nursing care, when patients decide whether or not to follow the recommendations made during nursing consultation.

It is his decision. (Gerbera)

Provide self-care, what he has to do at home. (Flame Lily)

Nurses expose the positions of trust, existing in health units for their coordination, which are often assumed by people who have neither mastery nor knowledge in their functions. They have status, without power or authority.

If someone was missing, we don't even notice. So, many times, even the problems at the unit, if we don't get ahead, there will be no change. Sometimes I keep policing myself, "you are the nurse, you are not the coordinator, I am not the coordinator, the coordinator is up there", [laughs] because lend up overloading myself. (Gerbera)

The results summarize nurses' perceptions, opinions and knowledge about Imogene King's concepts used (CMIOS).

\section{DISCUSSION}

In the personal system, nurses'attention to patients' perceptions is important. They must identify the changes that have occurred in the general health status, but also to the subjective aspects that signal dissatisfaction with their own life, aspects that can be addressed in consultation to identify problems, which are subject to nursing intervention. Even if human beings live in the same world and have common experiences, people differ in what they select to enter their perception ${ }^{(3)}$.

Another aspect of perception was how patients perceive nurses. In a study on the perception of patients with hypertension, it was revealed that patients see nurses as fundamental professionals for dialogue, clarification of the disease and its evolution, an incentive to maintain self-esteem ${ }^{(9)}$.

Body image was associated with vanity, with the demands of having a body accepted in society, but also in relation to health, care to prevent complications of the disease.

In this study, there was a gap in knowledge about self. We then sought to explore the concept by giving examples. One of the participants suggested selfies, photographs of himself to facilitate 
understanding. On the other hand, nurses can associate the use of self with the idea of companionship, patience, tolerance, respect, understanding each other and assessing themselves regarding their attitudes and behaviors ${ }^{(10)}$.

Concerning the concept of time, different from what nurses considered, patients think more about medication intervals, time of illness, time to go to health units and lack of time as a justification for not making changes in lifestyle for disease control ${ }^{(9)}$. Some statements were related to the waiting time that the patient usually complains about, especially the elderly, and which justify their impatience to wait for their turn.

It was observed that nurses are attentive to the space of interaction with patients. Be it in nursing consultation or in-home visit, there is an understanding of the need to respect the other's space, which is his/her own. The use of space is favorable and appropriate for establishing communication and interaction as well as respect for the other's space and time ${ }^{(10)}$.

As hypertension is mainly linked to adults, the concept of growth as a process of cell multiplication, weight gain, height was not considered by the group. The concept of growth was placed in the interpersonal system erroneously and interpreted in the sense that King grants to transaction.

There is an understanding of the importance of communication between nurse and patient. This should be effective, seeking appropriate language that will lead a person to understand the entire interaction with the health professional. They know the relevance of non-verbal communication in this interaction. Communication with other people involves the exchange of popular knowledge, based on their life experiences ${ }^{(9)}$.

The role of nurses is to articulate information during interaction with patients and families to develop care holistically. A study with bedridden elderly people and their family care revealed how much the role of patients changes as a result of illness, with distance from the obligations and responsibilities previously assumed by the position they occupied ${ }^{(11)}$.

King defended the need for nurses to view the practice environment holistically. Transactional relationships are the essence of nurse-patient interactions; an emotional connection or bond exists in the nurse-patient relationship, based on empathy and compassion; interaction requires art and science of nursing, critical thinking, attention, proactivity, empathy, anticipation, and assessment; patients are seen as a whole; assistance includes body, mind and spirit; effective communication includes listening, touching, collaborating and observing the patients' responses; clients are patient, family and health care staff; the responses of patients and families to the nurse-patient interaction are in the verbalization of "thank you", sound appreciation, physical response and patient registration ${ }^{(12)}$.

By presenting stress, Imogene King emphasizes that it is not seen primarily as a destructive force. Despite being taken more to the negative side, nurses were motivated to think about the positive aspect of stress, which led to an initial estrangement, but which was later revealed in the group ${ }^{(3)}$.

Among public health nurses, a study demonstrated no evidence of significant stress in FHS and considered that this environment has a positive influence on stress. The negative points were poor service and lack of clarification. Professionals had headache, physical tiredness and irritability, but that were not necessarily associated with the work environment ${ }^{(13)}$.

Through interaction, with a focus on goal setting and patient involvement, transactions influence customer behavior. Therefore, nurses assess the patients' functional status, so that they can reach their maximum potential, without generating false expectations regarding their performance ${ }^{(14)}$. Moreover, the scale produced to assess the nurse-patient interaction indicates that such interaction varies from low to high effectiveness in nursing care, covering a continuum. In the first level, there is the initial interaction with link building; in the second, communication is reciprocated; in the third, the transaction occurs through identification and respect in care; in the fourth, the interpersonal relationship deepens, with fun moments and family involvement and the top level of the scale is scored ${ }^{(15)}$.

When a transaction occurs, there is a change in nurse/patient interaction. Nurses reported that patients sometimes recognize their performance, considering it as the main element for orientations regarding medications (schedules, dosage) and changes in lifestyle. Patients note the individualized care when realizing that nurses put themselves on their shoes to better understand them ${ }^{(15)}$.

Transaction, when used in interdisciplinary teams, facilitates the definition of mutual goals with patients based on the knowledge and roles of a team. There must be congruence of role and respect for the knowledge, skills and values that each member brings to the situation ${ }^{(16)}$.

The idea of organization is proposed as a system with continuous activities aimed at goals, which promotes social forces that shape personal qualities and habits. It consists of human values, patterns of behavior, needs, goals and expectations; a natural environment, in which human and material resources are essential for goal attainment; employers and employees forming a group; and technology, which facilitates goal attainment ${ }^{(3)}$. Therefore, in order to meet the needs of patients and the evaluation of results, goals, planning and programs directed to the health needs of the social system are formulated, which are consistent with nursing practice. This is increasingly involved with care technologies, including Telehealth and can use the description of King's conceptual model in interactions, through personal, interpersonal, and social systems ${ }^{(17)}$.

Organization exhibits patterns of individual and group behavior, patterns of communication and interaction related to roles, authority, power, and status. Organizational requirements for nursing include the registration of activities performed in FHS, a current requirement for nursing work to have visibility ${ }^{(16)}$.

For nursing, it is relevant to visualize the power relations that exist in the daily routine of FHS. Power is associated with knowledge, involved in all nursing practices, which can transmit and reproduce the effects of power ${ }^{(18)}$. To better deal with the elements of power, dialogue and respect are essential tools when discussing team authority, hierarchy, power, and status ${ }^{(10)}$.

Reinforcing the concept of power, the authors proposed and validated the change in the concept, proposed by King, from the group's power capacity to the ability to achieve results, supported by the definitions used by her for the concepts of power and goals. Research has shown that nurses conceive of the idea of power as negative and not as a resource that, if used properly, nursing group empowerment ${ }^{(19)}$. The system members and their hierarchy must be respected, including the figure of the boss 
to facilitate the sum of individual performance, with a view to providing qualified assistance ${ }^{(20)}$.

Politics is a use of power in society, a process through which power is distributed and exercised, with an emphasis on collective decisions ${ }^{(3)}$. Thus, it is interesting to think that the nursing group can favor their empowerment in the health organization of the Unified Health System (SUS - Sistema Único de Saúde), with a view to better and greater achievements for nursing and society.

Provisions for direct or indirect nursing care require decisions for each nurse-patient situation and in each family. There was an improvement in adherence to treatment with diabetics, seen in glycemic and blood pressure parameters, and in raising awareness about the disease, when there was a foundation in the Theory of Goal Attainment ${ }^{(21)}$. When nurses engage with clients' health in mutual goals, they collaborate in making decisions between care options. Therefore, the implementation of nursing theories in practice promotes knowledge as the basis of a structure that guides the actions of nursing ${ }^{(22)}$.

Thus, including CMIOS can become a tool for planning nursing care for hypertensive patients, which was discussed by the study participants. Interaction of these two systems becomes more effective from a broader understanding of the concepts that involve the nursing situation.

\section{Study limitations}

A limitation is the fact that the research was carried out with only part of the municipality's nursing staff, which does not guarantee its full implementation.

\section{Contributions to nursing}

Understanding the CMIOS structure provides the necessary means to develop nursing care based on a theory. These are easy to understand concepts that, interrelated, provide a way to perceive patients, to notice themselves in this care relationship and to demonstrate their role in the health organization.

Considering that public health supports continuous monitoring of families and that, for this reason, professionals need means that facilitate their interaction and bonding, the idea that nurses can use a theoretical framework that supports their performance is defended with a view to empowering people.

We hope to contribute to nursing praxis, allowing a change in the perspective of nurses' performance to hypertensive patients, combining theory and practice in nurse-patient interaction. In the long run, this will allow greater appreciation of nursing as a science of care, as society itself can recognize the nurses' work in public health.

\section{FINAL CONSIDERATIONS}

After a collective discussion concerning CMIOS, the research participants not only demonstrated their perception of the concepts, but understood and related them to caring for people with hypertension. Thus, there was a consensus that nurses and patients interact with each other, but also with other professionals, with management, and that there is a hierarchy in SUS that interferes with their work process.

Nurses understand their role and responsibility towards hypertensive patients; however, they often settle without thinking about possible innovations, improvement to improve care and relationships with other professionals in the workplace.

It is important to recognize their role in the health organization as well as the other team members. This makes it possible to respect collective work, the objective of which is to assist people, families and the community from the perspective of empowerment. Therefore, King's conceptual framework can be used in FHS and base nursing care.

\section{REFERENCES}

1. Waldow VR, Fensterseifer LM. Saberes da enfermagem - a solidariedade como uma categoria essencial do cuidado. Esc Anna Nery. 2011;15(3):629-32. doi: 10.1590/S1414-81452011000300027

2. Borges JWP, Moreira TMM, Silva DB, Loureiro AMO, Meneses AVB. Relação enfermeiro-paciente adulto: revisão integrativa orientada pelo sistema interpessoal de King. Rev Enferm UFPE. 2017;11(4):1769-78. doi: 10.5205/1981-8963-v11i4Y2017p1769-1778

3. King I. A theory for nursing: systems, concepts, process. Tampa, Florida: Delmar Publishers. 1981.

4. Costa VRS, Costa PDR, Nakano EY, Apolinário D, Santana ANC. Alfabetismo funcional em saúde em pessoas idosas hipertensas na atenção primária. Rev Bras Enferm. 2019;72(supl2): 278-85. doi: 10.1590/0034-7167-2018-0897

5. Sociedade de Cardiologia do Estado do Rio de Janeiro. Manual de prevenção cardiovascular. São Paulo: Planmark; Rio de Janeiro: SOCERJ, 2017

6. Araújo ESS, Silva LF, Moreira TMM, Almeida PC, Freitas MC, Guedes MVC. Cuidado de enfermagem ao paciente com diabetes fundamentado na Teoria de King. Rev Bras Enferm. 2018;71(3):1092-1098. doi: 10.1590/0034-7167-2016-0268

7. Thiollent M. Metodologia da Pesquisa-ação. 18 ed. São Paulo: Cortez, 2011.

8. Spink M J. Práticas discursivas e produção de sentidos no cotidiano: aproximações teóricas e metodológicas. Rio de Janeiro: Centro Edelstein de Pesquisas Sociais, 2013.

9. Bezerra STF, Silva LF, Guedes MVC, Freitas MC. Percepção de pessoas sobre a hipertensão arterial e conceitos de Imogene King. Rev Gaúcha Enferm. 2010;31(3):499-507. doi: 10.1590/S1983-14472010000300013

10. Broca PV, Ferreira MA. Action plan for communication process in a nursing team. Acta Scientiarum. Health Sciences. 2016;38(1):23-31. doi: 10.4025/actascihealthsci.v38i1.29758 
11. Vieira LL, Freitas CASL, Brito MCC, Teófilo FKS, Silva MJ. The elderly and the family caregiver: The home care in the light of Imogene King. Rev Enferm UFPE. 2013;7(9):5500-9. doi: 10.5205/1981-8963-v7i9a11835p5500-5509-2013

12. Joseph ML, Laughon D, Bogue RJ. An examination of the sustainable adoption of whole-person care (WPC). Nurs Manag. 2011;19(8):989-97. doi: 10.1111/j.1365-2834.2011.01317.x

13. Fontana RT, Siqueira KI. O trabalho do enfermeiro em saúde coletiva e o estresse: análise de uma realidade. Cogitare Enferm. 2009;14(3):4918. doi: 10.5380/ce.v14i3.16179

14. Caceres BA. King's Theory of Goal Attainment: exploring functional status. Nurs Sci Quart. 2015;28(2):151-5. doi: $10.1177 / 0894318415571601$

15. Borges JWP, Moreira TMM, Andrade DF. Nursing Care Interpersonal Relationship Questionnaire: elaboration and validation. Rev Latino-Am. Enfermagem. 2017;25:e2962. doi: 10.1590/1518-8345.2128.2962

16. Killeen MB, King IM. Viewpoint: Use of King's Conceptual System, Nursing Informatics, and Nursing Classification Systems for Global Communication. Int J Nurs Terminol Classif. 2007;18(2):51-7. doi: 10.1111/j.1744-618X.2007.00050.x

17. Fronczek AE, Rouhana NA, Kitchin JM. Enhancing Telehealth Education in Nursing: Applying King's Conceptual Framework and Theory of Goal Attainment. Nurs Sci Quart. 2017;30(3):209-13. doi: 10.1177/0894318417708418

18. Velloso ISC, Ceci C, Alves M. Reflexões sobre relações de poder na prática de enfermagem. Rev Gaúcha Enferm. 2010;31(2):388-91. doi: $10.1590 / S 1983-14472010000200026$

19. Sieloff CL, Bularzik AM. Group power through the lens of the 21st century and beyond: further validation of the Sieloff-King Assessment of Group Power within Organizations. Nursing Management. 2011;19(8):1020-7. doi: 10.1111/j.1365-2834.2011.01314.x

20. Broca PV, Ferreira MA. Processo de comunicação na equipe de enfermagem fundamentado no diálogo entre Berlo e King. Esc Anna Nery. 2015;19(3):467-74. doi: 10.5935/1414-8145.20150062

21. Araújo ESS, Meneses LCG, Vieira LA, Barros AA, Moura NS, Guedes MVC. Intervenções educativas à pessoa com diabetes fundamentada na Teoria de King. Rev Enferm UFPE. 2017;11(2):515-22. doi: 10.5205/1981-8963-v11i2a11969p515-522-2017

22. Brandão MAG, Martins JSA, Peixoto MAP, Lopes ROP, Primo CC. Reflexões teóricas e metodológicas para a construção de teorias de médio alcance de Enfermagem. Texto contexto Enferm. 2017;26(4): e1420017. doi: 10.1590/0104-07072017001420017 